\title{
Anomalies of the Sea Surface Temperature in the Indonesian Throughflow Regions: A Need for Further Investigation
}

\author{
B.R. Manjunatha ${ }^{1, *}$, K. Muni Krishna ${ }^{2}$ and A. Aswini ${ }^{2}$ \\ ${ }^{I}$ Department of Marine Geology, Mangalore University, Mangalagangotri, India \\ ${ }^{2}$ Department of Meteorology and Oceanography, Andhra University, Visakhapatnam, India
}

\begin{abstract}
Indonesian throughflow (ITF) regions are important in terms of inter-oceanic exchange of heat as well as freshwater between the Pacific Ocean and the Indian Ocean. These regions also linking the North Pacific Ocean and North Atlantic through a global conveyor belt. However, information about the long-term variations of sea surface temperature (SST) across the ITF regions is rather limited. Here, we use long-term Hadley sea surface temperature and advance satellite-derived sea-surface winds to understand long-term changes in and around the ITF. The SST has been lower during the summer season (May-August) with a pronounced minimum in the eastern Indonesia region (INA) and then decreases towards the west due to the activity of southeasterly monsoon winds. The cooling is noticed in the beginning of May, intensifies during July and subsides during the later half of August. The Lambok Strait has been identified as the coolest region $\left(<26^{\circ} \mathrm{C}\right)$ in the ITF. Though there has been a general agreement of warm and cool SSTs with El Niño and La Niña conditions respectively, and increasing trend since 1970s, however, there is no consensus among the major passages in the ITF, suggesting complex internal dynamic processes those need to be studied.
\end{abstract}

Keywords: El nino, indonesian throughflow, lanina, sea surface temperature.

\section{INTRODUCTION}

The Indonesian throughflow (ITF) is one of the important inter-oceanic exchange regions in the global ocean. It has long been the centre of focus of research interest due to its strategic region of not only the current, but also past regional and global ocean circulation patterns. This region, particularly, imperative because of the exchange of water and heat between the Indian Ocean (IO) and Pacific Ocean. It transfers warm and low-salinity waters from the Western Pacific into the IO, where the Asian Monsoon gathers strength. As an integral part of the global ocean circulation, ITF is important in regulating the climate and rainfall across Indonesia, India and Australia.

The ITF is the system of surface currents flowing from Pacific to Indian Ocean (IO) through the Indonesian Sea and joins the Indian Ocean along South of Java, Australia and Indonesian archepilago through the activity of South Equatorial Current (SEC) along three major passages Lombok $\left(115^{\circ} 50^{\prime} \mathrm{E}, 8^{\circ} 30^{\prime} \mathrm{S}\right)$, Savu or Ombai $\left(122^{\circ} \mathrm{E}, 9^{\circ}\right.$ $\left.30^{\prime} \mathrm{S}\right)$ and Timor $\left(128^{\circ} \mathrm{E}, 11^{\circ} \mathrm{S}\right)$. The Indonesian region is also known as the "Maritime Continent" because of its unique topography and other physio-dynamical characteristics [1]. It experiences two monsoons seasons in a year, i.e., southeast monsoon season (June to September),

*Address correspondence to this author at the Department of Marine Geology, Mangalore University, Mangalagangotri, India;

E-mail: omsrbmanju@yahoo.com northwest monsoon (January to March) separated by two transitional phases between these two monsoon seasons [2]. The SE monsoon on one hand, is the dry season that associated with easterlies from Australia that transports warm and dry air over the region. On the other hand, the NW monsoon is the rainy season which is associated with westerlies from the Eurasian continent that carry's warm and moist air to the Indonesian region [3-4].

Indonesian region is one of the primary links of the global exchange of water and heat between ocean basins and hence, it is an essential component of the global climate system. It also acts as an oceanic connection between the warm pools of the Pacific and Indian Oceans. The sea surface temperature variations within the Indonesian region are a consequence of the complex physiography and connectivity between the two major oceans [1]. The sea surface temperature variability across the ITF region plays a vital role of convection for yielding surplus rainfall. Therefore, the development of a deep convective cell over the region is due to the enormous amount of evaporation of ocean water that triggered by the increase SSTs in the form of surface heat flux around the islands of the ITF region. Several studies carried out around the IFT regions [5-8] reveal that the convective activity is regulated by the SST as both modeling as well as observations show that minor changes in the SST within the ITF region can results in the momentous alterations of rainfall patterns across the interoceanic exchange region. This has widespread implications on climate and economy of the region. 
The ITF is strongly presides over by pressure gradient between the Pacific Ocean and Indian Ocean from seasonal to inter-annual time scales. Makassar Strait is the primary path of the ITF where the flow is maximum during the southeast monsoon and lean flow during the northeast monsoon. The warm (El Nino) and clod (La Nina) currents in the equatorial region changes the pathways of ITF and its characteristics. The area of investigation and the main pathways of the ITF are shown in Fig (1). Therefore, the main objectives of this study are to determine the seasonal and inter-annual variations in SST in the main transaction of the ITF and the possible role of south-east Asian monsoon in regulating the SST of the ITF.

\section{METHODOLOGY}

Since there are no direct observational long-term time series data of SST for the ITF, the satellite monitored data of same have been taken from the Hadley Centre, Meteorological Office, UK. These data (HadISST1) are better than the global sea surface temperature (GISST) data as they are unique in terms $1^{\circ}$ latitude-longitude resolution covering the global ocean since 1870 (http://www. metoffice.gov.uk/hadobs/hadisst/). The global Sea surface winds data are available at a better resolution $\left(0.25^{\circ}\right.$ latitudelongitude grid) than the HadSST data. However, monthly average data available since 1988 [9]. Furthermore, the wind field data are taken from the National Climate Data Centre (www.ncdc.noaa.gov).

\section{RESULTS AND DISCUSSION}

The variations of SST in the ITF region are generally not much as compared to that in the Tropical Pacific Ocean due to the lack of strong equatorial upwelling. However, small variations in SST at this region (ITF) can significantly affect the atmosphere-ocean interaction processes. Fig. (2) depicts the monthly climatology of the HadSST data of the study region. It is clear from the Fig. (2) that the largest variations of the SST occur in the Makassar which is the main region of the ITF. To some extent, Ombai, Lambok, Timor as well as the South China Seas are other regions, where the SST ranges between 27.5 and $30^{\circ} \mathrm{C}$. However, during October December, the SST found $\left(27-30^{\circ} \mathrm{C}\right)$ to be little variations in the ITF. The temperature of Makassar region of the ITF has been moderately lower $\left(27.5-29.5^{\circ} \mathrm{C}\right)$ almost throughout the year.

Overall, the variations in SST at ITF region from SE monsoon season to NW monsoon season is $\sim 1^{\circ} \mathrm{C}$. The monthly wind vectors map (Fig. 3) clearly reveals the influence of sea surface winds on SST variations at this region. On one hand, the eastern part of the ITF region experiences a prominent decrease of SST during the NW monsoon season. On the other hand, SST is relatively high in the western part of the ITF region. The spatial and temporal scales of SST in the eastern part of the ITF are due to southeasterly wind arriving from the Australian continent that drives the upwelling (Ekman pumping). This onservation is in agreement with the studies carried out earlier $[2,10]$.

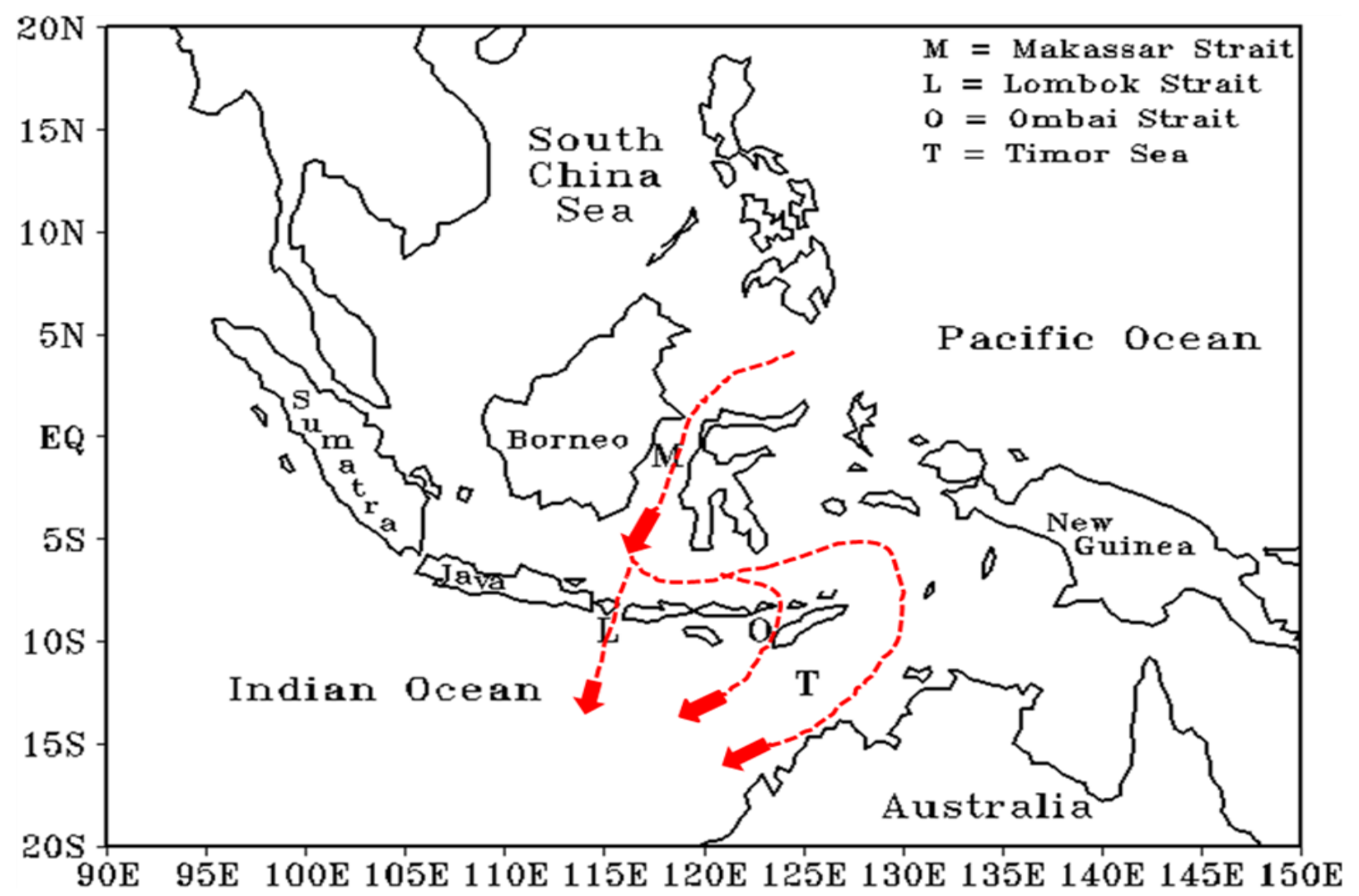

Fig. (1). Map of the Indonesian Throughflow (ITF) and it primary passages linking Pacific Ocean with the Indian Ocean. The red dashed lines indicate four important passages denoted with $\mathrm{M}, \mathrm{L}, \mathrm{O}$ and $\mathrm{T}$ of the ITF flow. 

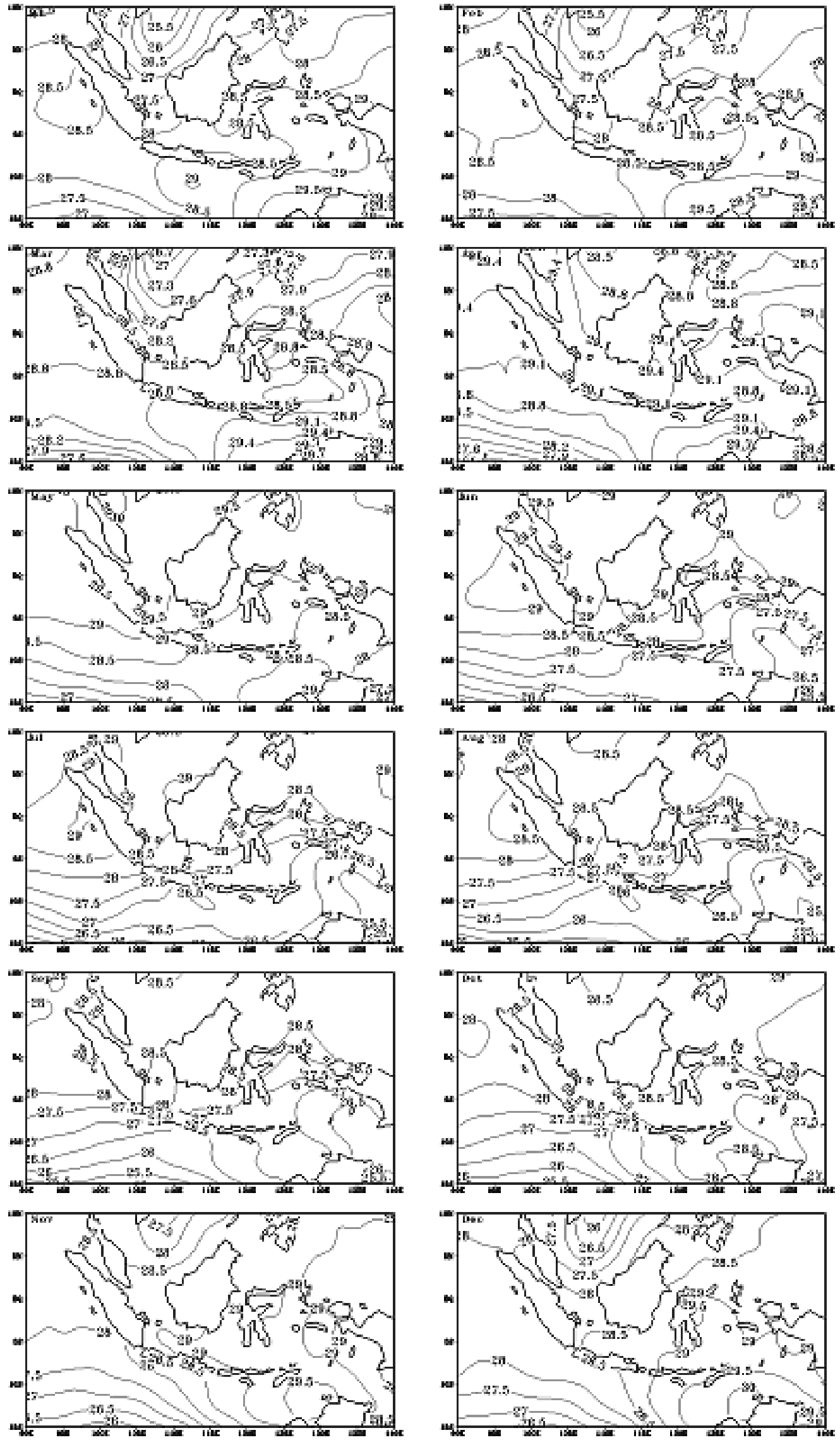

Fig. (2). Average monthly climatology of the Hadley SST over different passages in the ITF. 

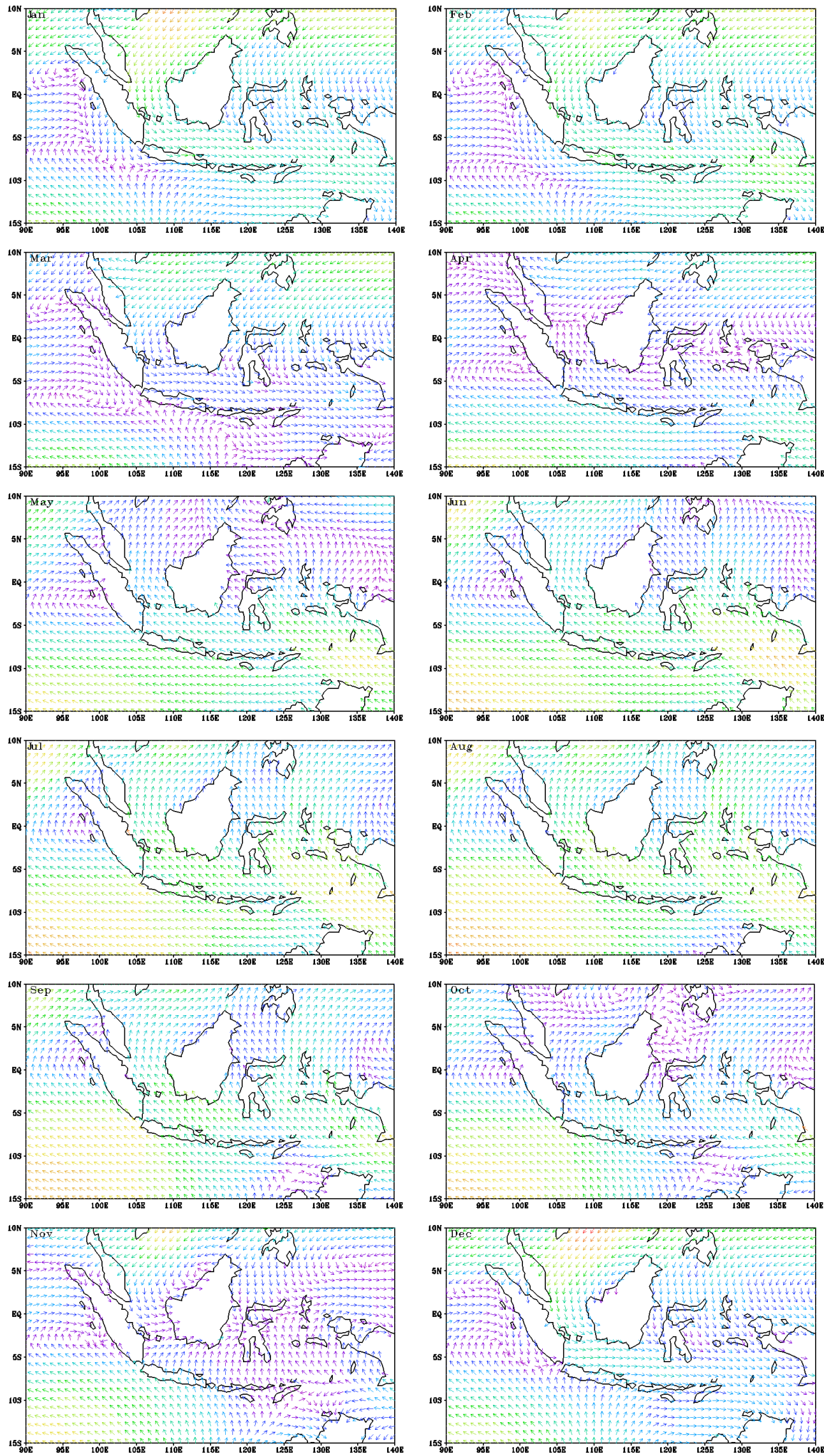

Fig. (3). Average monthly climatology of the wind speed over the ITF region. 
During the month of April, the main path regions are covered by SST $\sim 29.5^{\circ} \mathrm{C}$ (Fig 2). Fig. (3). shows that generally the lowest wind speed appear during April, which represents the month of transition between NW and SE monsoons [3-4]. Because of the weak winds and large sea surface heating due to solar radiation, water stratification is well developed during this month. These results in a uniform SST field in the Makassar, Lambok, Ombai and Timor regions. During the May, sea surface cooling begins at the eastern part of the ITF. Further, the strengthen winds during the month of June leads to the intensification cooling that expanding along the wind direction from the Makassar strait. Similarly, the lower SST areas are observed at the Lambok and Timor Seas.

More than $1.5^{\circ} \mathrm{C}$ drop down in SST observed at the Lambok Strait and Timor Sea during the July that records lowest SSTs caused by the SE monsoon winds. Similarly, the lower SSTs during the August (Fig. 2), can be attributed to attributed to the Wyrtki's Role $[4,10,11]$. During this month, very strong winds blow over the ITF region, particularly in the Lambok and the Timor Sea. Similarly, the intensification of SW winds leading to the decrease in SST of the Java Sea has been noticed by the earlier workers [2]. The increase of SST in the ITF region noticed during the beginning of September as a result of the weakening of surface winds. This continues to rise SST $\left(>28^{\circ} \mathrm{C}\right)$ during
October particularly in the ITF region with the exception of Lambok and Ombai coastal areas.

The inter-seasonal variations of SST at four important pathways of the ITF regions are shown in Fig. (4). The most significant intrusion in the ITF is noticed at Makassar Strait. This region records an increasing trend of the SST $\left(>1.5^{\circ} \mathrm{C}\right)$ during almost all months in a year, starting from 1980 onwards. The increase of SST has been dramatic $\left(\sim 2^{\circ} \mathrm{C}\right)$ during El Nino years (1982, 1998 and 2002).

Nevertheless, a weak warming trend of SST $\left(\sim 0.6^{\circ} \mathrm{C}\right)$ observed in the Lambok Strait especially from January to April and December months, whereas, remaining months, no significant variations observed. During the SE monsoon season, cooling of the sea surface occurs from middle of June to October before 1980s, however, this has not been the case during the middle of July to middle of September. This indicates that the SE monsoon winds increasing the SST at Lambok Strait. This trend is also observed at the Ombai Strait, however, but the temperature rise is more than $0.5^{\circ} \mathrm{C}$ during December. The cooling of sea surface at this region observed to be considerably important from middle July to September. There is no clear trend in the SST at Timor Sea, although an increasing trend noticed since the year 2000 . Similarly, little rise in SST observed during January to middle of March and December months.

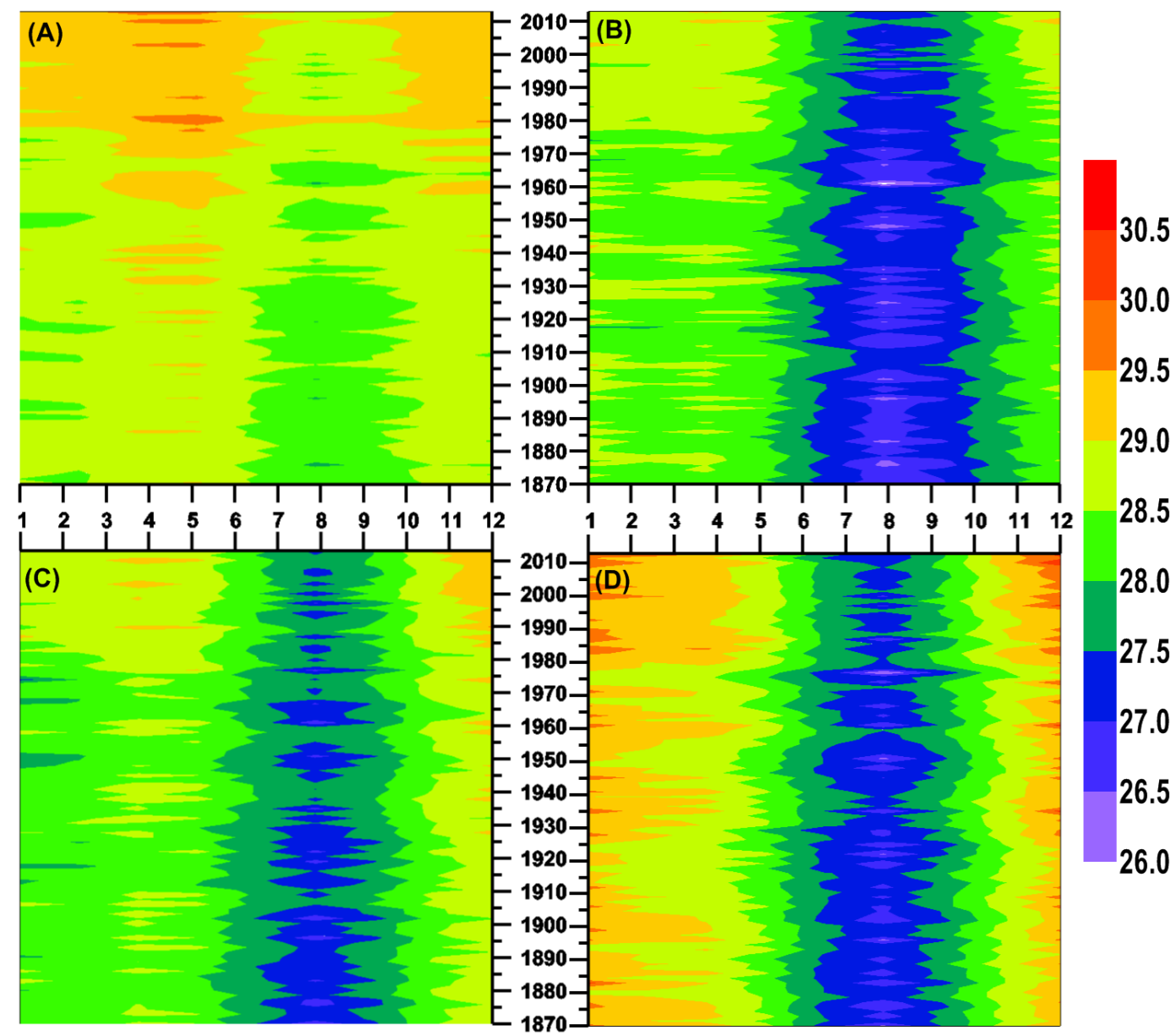

Fig. (4). Intra-seasonal variations of sea surface temperature at, (a) Makassar Strait, (b) Lambok Strait, (c) Ombai Strait and, (d) Timor Sea during 1870-2013. 
In order more fully understand the long term trend (18702013) of SST in the ITF region, annual time series analysis has been performed for the selected regions - M, L, O and T (Fig. 1) which are in deed the main pathways of the ITF (Fig. 5). Now it is quite clear that at most of locations, minima and maxima SST coinciding with the La Nina and El Nino years. The long term data (1870-2013) show that there is no significant increase in SST in the Timor Sea as compared to that for the Makassar Strait $\left(0.28^{\circ} \mathrm{C}\right.$ and $0.49^{\circ} \mathrm{C}$ respectively). However, during the global warming era, Timor Sea records almost $1^{\circ} \mathrm{C}$ increase since 1970, while there has been no change in the SST of Makassar Strait. The increase of SST at Ombai and Lambok are intermediate $\left(0.86^{\circ} \mathrm{C}\right.$ and $\left.0.91{ }^{\circ} \mathrm{C}\right)$ between those noticed at Makassar Strait and Timor Sea. These results are consensus with previous studies $[2,11]$. All these suggest a complex internal dynamics in the water column control SST in the ITF region. Therefore, a detailed study needs to be carried out to understand the different mechanism behind the strong warming at the above regions.

\section{IMPLICATIONS}

We have provided a general description of SST variability in the Indonesian region and its distribution surrounding oceans. As the SST variability in the ITF region has great impact on regional climate, environment, economy, and biological productivity, we hope that this study will be useful for future studies. The SST distributions in the ITF region are complex, varying considerably both in space and time. The complexity makes it difficult to understand the processes that control the SST variability. Within the Indonesian archipelago, local monsoon winds and tidal mixing are important in explaining the mean seasonal SST cycle. These processes, however, become less important on longer time scales; the interannual SST variability can be largely understood by regional/global atmosphere/ oceanographic processes. The variations in the SST of the
Indonesian region are not only important in understanding the air-sea interactions, but also have global climate implications. It also affects the dynamics of the strongest western boundary current (Aghulas Current) existed in Indian Ocean. Convection in the upper sea water column depends upon on the variations in the SST, which is dominant process over the ITF region. Convective activity in the ocean water column drives atmospheric circulation and thereby contributing to energy for global moisture budgets. Therefore, it is important to study SSTs variations for predictive climate models.

\section{SUMMARY AND CONCLUSIONS}

In this work, the major objective was to know the longterm variations of SST (since 1870) in the Indonesian Throughflow Regions to understand role of south-east Asian monsoon along with regional/global atmospheric/ oceanographic processes. The SST found to be lower during the summer with a pronounced minimum in the eastern Indonesia region and further decreases towards the west as a result of the intensification of southeasterly monsoon. However, the cooling begins during May, intensifies during July and then decreases during August. The Lambok Strait records the lowest SST $\left(<26^{\circ} \mathrm{C}\right)$ in the ITF. Although the warm and cool SSTs are parallel with El Niño and La Niña conditions, there are increasing trends of SST since 1970. The combination of Hadley SST and NOAA blended sea-surface winds in the ITF regions suggest that there is no consensus in the SST among the major passages connecting the Indian Ocean with the Pacific Ocean. This suggests complex internal dynamics processes operating in the water column those need to be studied.

\section{CONFLICT OF INTEREST}

The authors confirms that this article content has no conflict of interest.

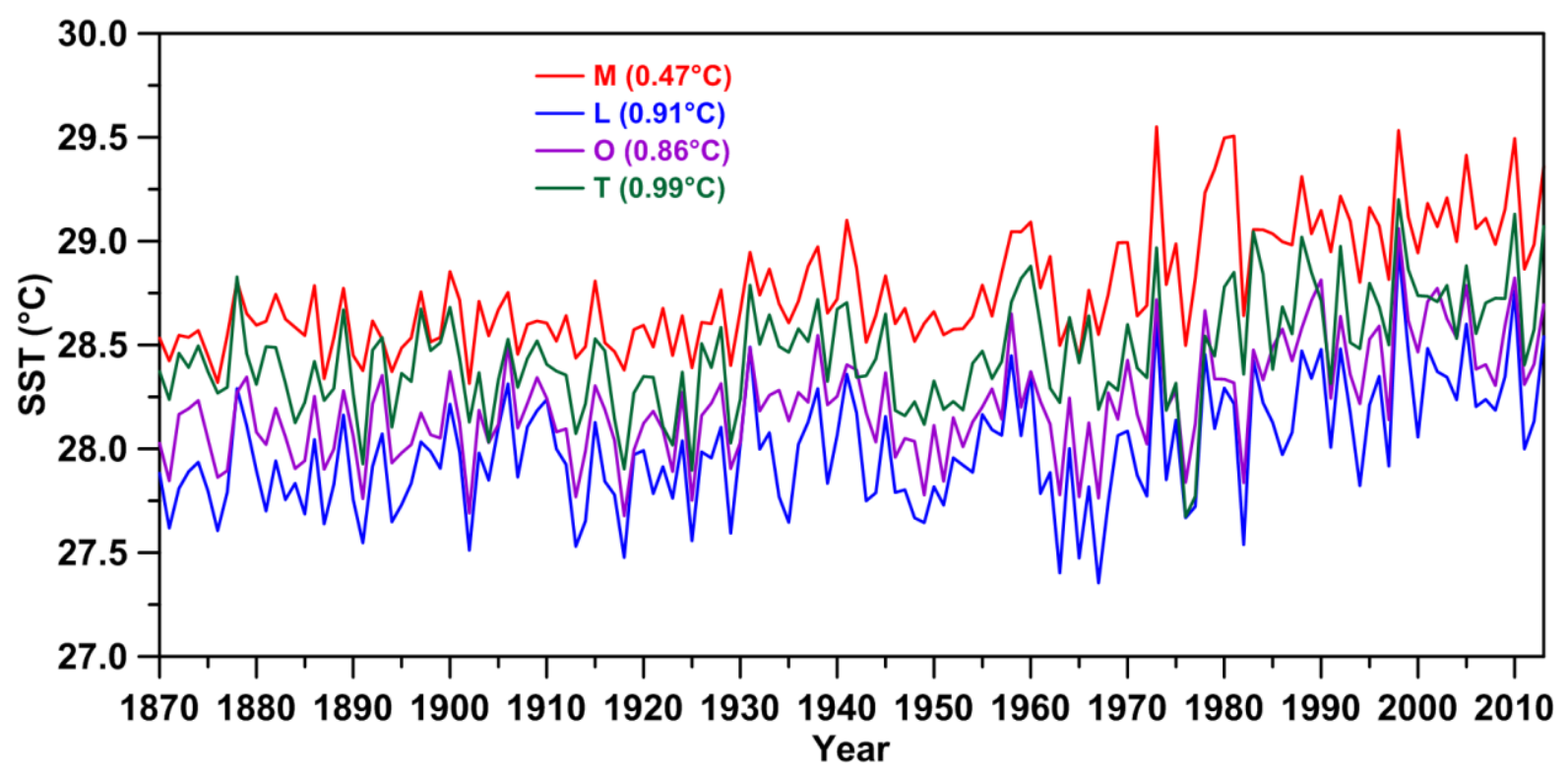

Fig. (5). Time-series of annual sea surface temperature at different pathways of the ITF (please see pathway locations mentioned in Fig. (1). The parentheses represent the increase in SST increasing trend during 1970-2013 period. 


\section{ACKNOWLEDGEMENTS}

All authors grateful to U.K. Met Office and NOAA for the sea surface temperature and blended wind field data. We also extend our gratitude to two anonymous reviewers for their constructive comments and suggestions for the improvement the manuscript.

\section{REFERENCES}

[1] Qu T, Du Y, Strachan J, Meyers G, Slingo J. Sea surface temperature and its variability in the Indonesian region. Oceanography Magazine, 2005, 18 (4): 50-61.

[2] Setiawan RY, Habibi A. SST cooling in the Indonesian seas. Ilmu Kelautan Maret 2010; 15(1): 42-46.

[3] Gordon AL. Oceanography of the Indonesian seas and their throughflow. Oceanography Magazine 2005; 18(4): 14-27.

[4] Wyrtki K. Physical Oceanography of Southeast Asian waters. NAGA Report, 1961, Vol. 2, Scripps Institution of Oceanography, La Jolla, CA, 195.
Miller MJ, Beljaars ACM, Palmer TN. The sensitivity of the ECMWF model to the parameterization of evaporation from the tropical oceans. J Clim 1992; 418-434.

[6] McBride JL, Haylock MR, Nichols N. Relationships between the maritime continent heat source and the El Niño-Southern oscillation phenomenon. J Clim 2003; 16(2): 905-2,914.

[7] Ashok K, Guan Z, Yamagata T. Impact of the Indian Ocean Dipole on the relationship between Indian Ocean monsoon rainfall and ENSO. Geophys Res Lett 2001; 28(4): 499-4,502.

[8] Neale, RB, Slingo JM. The Maritime Continent and its role in the global climate: A GCM study. J Clim 2003; 16: 834-848.

[9] Zhang HM., Bates JJ, and Reynolds RW. Assessment of composite global sampling: Sea surface wind speed. Geophys Res Lett 2006; 33, L17714, doi:10.1029/2006GL027086.

[10] Susanto RD, Moore T, Marra J. Ocean color variability in the Indonesian seas during the SeaWifs Era. Geochem Geophys Geosyst 2006; 7(5): 1-16.

[11] Sprintall J, Liu T. Ekman mass and heat transport in the Indonesian seas. Oceanography Magazine 2005; 18 (4): 88-97.

(c) Manjunatha et al.; Licensee Bentham Open.

This is an open access article licensed under the terms of the Creative Commons Attribution Non-Commercial License (http://creativecommons.org/licenses/by-nc/3.0/) which permits unrestricted, non-commercial use, distribution and reproduction in any medium, provided the work is properly cited 